UDK 811.163.42’373.46:81

811.163.42'36(091)

Izvorni znanstveni rad

Rukopis primljen 27. XI. 2019.

Prihvaćen za tisak 23. I. 2020.

Marijana Horvat

https://doi.org/10.31724/rihjj.46.1.5

\title{
Martina Kramarić
}

Institut za hrvatski jezik i jezikoslovlje

Ulica Republike Austrije 16, HR-10000 Zagreb

mhorvat@ihjj.hr

mkramar@ihjj.hr

\section{JEZIKOSLOVNO NAZIVLJE U GRAMATIKAMA M. A. RELKOVIĆA I G. VINJALIĆA ${ }^{1}$}

U članku se analizira jezikoslovno nazivlje u dvjema gramatikama iz 18. st., Relkovićevoj Novoj slavonskoj, i nimačkoj gramatici ('1767.) i Vinjalićevoj rukopisnoj gramatici Principi della grammatica [...] Grammatica prima in lingua slava, italiana et latina.

Relkovićeva je gramatika prva vrlo opsežna gramatika hrvatskoga jezika pisana hrvatskim jezikom, i to kontrastivno, u suodnosu prema njemačkome jeziku. Rukopisna Vinjalićeva gramatika pisana je trojezično, a donedavno uglavnom nije bila predmetom interesa jezikoslovne javnosti.

Kako svaki naziv u promatranim gramatikama nema uvijek svoju hrvatsku inačicu, nužno je bilo u istraživanju osvrnuti se i na latinsko nazivlje jer su promatrane gramatike pisane prema latinskomu modelu. Budući da su u postojećim potvrdama hrvatskoga nazivlja uočene sličnosti s prethodnicima (npr. s nazivljem u J. Mikalje, L. Šitovića, T. Babića, B. Tadijanovića), primjeri su stavljeni u kontekst izgradnje hrvatskoga jezikoslovnog nazivlja. Stoga se ovim radom nastoji pokazati koliko su se u izgradnji hrvatskih naziva dvojica promatranih gramatičara rukovodila uporabnom normom i već ovjerenim modelima u tvorbi novih naziva te koliko se njihovim novotvorbama koriste kasniji gramatičari.

1 Ovaj je rad financirala Hrvatska zaklada za znanost projektima Retrodigitalizacija i interpretacija hrvatskih gramatika do ilirizma (IP-2018-01-3585) i Hrvatsko jezikoslovno nazivlje - Jena (STRUNA-2017$-09-05)$. 


\section{Uvod}

Hrvatski jezik ima dugu tradiciju gramatičkih opisa, a u skladu s tadašnjim europskim gramatikama i hrvatske se rane gramatike temelje na tradiciji latinskih gramatika. Riječ je uglavnom o preradbama gramatike portugalskoga isusovca Manuela Álvaresa i obradbama gramatike Józsefa Grigelya. Prve hrvatske gramatike slijede tzv. alvaresovski model. U metodi opisa do promjena dolazi početkom 19. stoljeća kad austrijska vlast za školsku uporabu propisuje gramatiku J. Grigelya (Institutiones Grammaticae in usum scholarum grammaticarum regni Hungariae et adnexarum provinciarum, Budae, 1807. - 1809.), a promjene se posebice odnose na područje sintakse (Demo 2007: 40). ${ }^{2}$

S obzirom na zapadnu usmjerenost hrvatskoga jezika i književnosti, dugu tradiciju pismenosti na latinskome jeziku te prevođenja s latinskoga jezika, latinski je jezični utjecaj primaran i u gramatičkim opisima na svim razinama. Poznato je stoga da su prve hrvatske gramatike ili pisane na latinskome jeziku ili opisuju latinski jezik, što je i u skladu s hrvatskim školstvom koje je dugo bilo pod utjecajem latinskoga jezika. Uz latinski jezik prisutan je i talijanski, a od 18. stoljeća i njemački jezik.

Kao i u većini drugih jezika, prve su hrvatske gramatike nastale u okviru crkvenih redova, katoličkih isusovaca i franjevaca, a služile su za poučavanje redovničke mladeži hrvatskomu ili latinskomu jeziku. Podsjetimo da je Bartol Kašić, autor prve hrvatske gramatike Institutionum linguae Illyricae libri duo (1604.), bio isusovac. ${ }^{3}$ Upravo isusovačkomu redu pripada zasluga za znatno unaprjeđenje školstva Banske Hrvatske od njihova dolaska na Kaptol 1606. do ukidanja

\footnotetext{
2 Bosanski franjevac Stjepan Marijanović prvi je Hrvat koji je napisao (1822., 1823.) cjelovitu gramatiku u koju je uključena Grigelyeva sintaksa padeža (usp. Demo 2007: 40-41). Riječ je o gramatici Institutiones grammaticae Latinae idiomate Illyrico propositae ad usum iuventutis provinciae Bosnae Argentinae compilatae (Split, 1822.) i Syntaxis linguae Latinae iuventuti Bosnae Argentinae accommodata (Venetiis, 1823.). Marijanovićeva slovnica latinskoga jezika pisana hrvatskim metajezikom pripada kontekstu bosanskohercegovačke gramatikografije bosanskih franjevaca koja se temeljila na obradbi gramatike Józsefa Grigelya Institutiones Grammaticae in usum scholarum grammaticarum regni Hungariae et adnexarum provinciarum (Budae, 1807. - 1809.).

3 Na utemeljenoj Akademiji ilirskoga jezika (Academia linguae Illyricae 1599.) pri isusovačkome kolegiju u Rimu Bartol Kašić postavljen je za prvoga učitelja ilirskoga jezika. Na toj su Akademiji budući misionari, koji su u vrijeme vjerske obnove slani u hrvatske krajeve, trebali naučiti jezik hrvatskoga puka. Kašić je dobio zadatak da za potrebe nastave napiše priručnik po kojemu bi studenti trebali učiti gramatiku ilirskoga (hrvatskoga) jezika.
} 
reda 1773. godine. Ustroj isusovačkih gimnazija temeljio se na smjernicama europskoga isusovačkog sustava zapisanoga u Ratio studiorum (1599.). Nastavni jezik bio je latinski, učili su se i starogrčki i hebrejski, ali materinski jezik nije bio zanemarivan jer se prevodilo s njega i na njega. Iz toga se razvila potreba za jezičnim priručnicima (rječnicima, gramatikama) na materinskome jeziku. To je bio poticaj za nastanak Habdelićeva Dictionara (rječnik iz 1670.) i gramatika latinskoga jezika u kojima se pravila objašnjavaju kajkavskim književnim jezikom.

Poznato je također da je franjevačka djelatnost bila, osim na bosanskome tlu, veoma izražena i na širemu hrvatskom prostoru, ponajprije u Dalmaciji i Slavoniji. „Brojni rječnici i gramatike koje su franjevci sastavili služili su da se prijeđe prag u drugih jezikâ i kulturâ te da razlika u jeziku ne bude zapreka u nastojanju za općim dobrom svih kršćana i nekršćana, vjernika, 'poluvirnih' ili inovjeraca." (Bratulić 2013: 62-63).

Franjevačka je književna produkcija osobito važna i zbog njezine uloge u procesu standardizacije hrvatskoga jezika na štokavskoj osnovici jer franjevački pisci rade na reformi jezika i stila, težeći za općim jezičnim standardom kojim bi se premostile razlike i zadovoljio što veći broj čitatelja. Njihov jezik stoga karakterizira prepoznatljiva i prilično ujednačena uporabna norma, što je utjecalo na standardizacijska kretanja.

U ovome radu istražit će se jezikoslovno nazivlje u Novoj slavonskoj i nimačkoj gramatici (1767.) Matije Antuna Relkovića i u gramatici Principi della grammatica [...] Grammatica prima in lingua slava, italiana et latina (18. st.) Gašpara Vinjalića. Relkovićeva je gramatika odabrana stoga što je riječ o prvoj vrlo opsežnoj gramatici hrvatskoga jezika pisanoj hrvatskim jezikom (istina kontrastivno, u suodnosu prema njemačkomu jeziku), a rukopisna Vinjalićeva zbog dosadašnjega slaba interesa jezikoslovne javnosti za tu slovnicu.

O jezikoslovnome nazivlju u starim hrvatskim gramatikama, rječnicima i dopreporodnim tekstovima postoje pojedinačni radovi. ${ }^{4} \mathrm{Za}$ potrebe ovoga rada spomenut ćemo izrijekom one koji obrađuju Relkovićevo nazivlje ili ga se impli-

\footnotetext{
4 Npr. Ptičar 1992: 151-156, Gabrić-Bagarić 1997: 55-61, Brlobaš i Horvat 2006: 49-66, Lewis, Štebih i Vajs 2006: 183-201, Gabrić-Bagarić i Horvat 2008: 116-123, Horvat i Ramadanović 2012: 330-331, Perić Gavrančić 2015. Iako jezikoslovno nazivlje nije primaran predmet opisa, dotiče ga se i u Tafra 1993, Ham 2006.
} 
citno dotiču. Jezikoslovno nazivlje Relkovićeve gramatike djelomice je već bilo predmetom zanimanja znanstvenih studija, u kojima se ono taksativno popisalo (Maretić 1932, Ptičar 1987). Dragutin Raguž (1980-1981) je, pak, pišući o nazivlju u gramatikama Tome Babića i Lovre Šitovića, istaknuo njihove prvopotvrđenice, kao i poneki od naziva koji se $u$ istome obliku i značenju pojavljuje $u$ Relkovićevoj i drugim onodobnim slovnicama, upućujući na postojanje uporabne norme na franjevačkim kolegijima i na kontinuitet te norme u kasnijim gramatikama. Neke Relkovićeve jezikoslovne nazive spominje i Ljiljana Kolenić (2006). Relkovićevu je gramatiku na svim jezičnim razinama opisao Ivo Pranjković (1985). Jezikoslovcu i književniku Relkoviću bili su posvećeni znanstveni skupovi koji su rezultirali zbornicima objavljenih radova (1991., 2000.). S druge strane, nazivlje u Vinjalićevoj gramatici dosad nije iscrpno obrađeno. ${ }^{5}$

\section{Relkovićeva i Vinjalićeva gramatika i prethodni gramatičari}

Matija Antun Relković bio je vojnik koji je obrazovanje stekao u franjevačkome samostanu u Cerniku, a potom u Pečuhu. U gramatičarskome radu oslanjao se na svoje prethodnike.

Relkovićeva je gramatika vrlo opsežna (ima gotovo 600 str.) kontrastivna gramatika. Pisana je hrvatskim jezikom, ali se gotovo sve paradigme i pravila donose i na njemačkome jeziku. Hrvatski se jezik temelji na štokavskoj ikavici, ali se u obzir uzimaju sva tri narječja, pogotovo u leksiku. Kao što je to tad bilo uobičajeno, ni Relkovićeva slovnica ne opisuje samo gramatičko ustrojstvo jezika, nego je opći jezični priručnik, za što su uzori postojali u domaćim i europskim jezičnim priručnicima, npr. njemačkim i francuskim. Ona je i dobar izvor jezikoslovnoga nazivlja. Nastala je u prosvjetiteljskome duhu. Relković sam objašnjava da gramatiku piše s namjerom očuvanja vlastitoga jezika, ali i da bi mladež iz nje mogla učiti njemački jezik, a Nijemci hrvatski.

Gramatiku su opisali Vinko Kovačić (Trojezična gramatika fra Gašpara Vinjalića: struktura i usporedba. Poglavlja iz romanske filologije: u čast akademiku Augustu Kovačecu o njegovu 80. rođendanu. Ur. Lanović, Nina; Ljubičić, Maslina; Musulin, Maša; Radosavljević, Petar; Šoštarić, Sanja. FF press. Zagreb. 2018.) i Martina Kramarić (2020.), koji također spominju neke od naziva. Kako članak V. Kovačića još nije bio objavljen u vrijeme našega rada na ovome članku (iako nosi 2018. kao godinu tiskanja), moguće je da smo neovisno o njegovu članku došli do istih spoznaja unatoč tomu što se njime nismo mogli služiti. 
Gašpar Vinjalić bio je redovnik, franjevac. Svoju je gramatiku napisao sredinom 18. st., a sačuvana je u rukopisnome prijepisu iz 1809., koji se čuva u Arhivu Franjevačkoga samostana u Sinju. Vinjalićeva je gramatika, uz Šitovićevu i Babićevu, jedna u nizu pisanih za franjevačke škole u 18. st. Ta još uvijek neobjavljena gramatika dugo je bila u sjeni zanimanja znanstvene javnosti te o njoj nema puno poznatih podataka. Kako to sam autor navodi, namijenjena je poučavanju redovničke mladeži hrvatskomu jeziku, ali istodobno i latinskomu i talijanskomu. Stoga je gramatika uistinu koncipirana trojezično: pravila se navode najčešće na talijanskome i latinskome jeziku, a primjeri su trojezični. U tim okolnostima opis i primjeri na hrvatskome jeziku prilagođavaju se latinskomu ili talijanskomu jezičnom sustavu. Hrvatski se jezik, dakle, u gramatici predstavlja modelom drugoga jezika, kao što je to slučaj i s prvom gramatikom hrvatskoga jezika. Među glagolskim oblicima tako se navode i supin (ne u današnjemu značenju), participi, gerund, što je sve uobičajeno za hrvatske gramatike koje prate latinski model. Da slijedi Álvaresovu gramatiku, doznaje se i preko eksplicitnih uputa: „Vide Emmanuel”. ${ }^{6}$ Hrvatska jezična sastavnica, koja se uočava u primjerima, ali i u popisu riječi na kraju jezičnoga dijela gramatike, raznonarječna je, ${ }^{7}$ ali ipak Vinjalić prednost daje značajkama štokavske ikavice s elementima jekavice pred čakavskim značajkama te štokavskomu leksiku, u čemu se očituje utjecaj dubrovačke i primorske književnosti te bosanske franjevačke književnosti. U primjerima je zastupljen i narodni leksik.

Budući da su u postojećim potvrdama hrvatskoga nazivlja iz tih dviju gramatika uočene sličnosti s prethodnicima (npr. s nazivljem u gramatikama Jakova Mikalje, Lovre Šitovića, Tome Babića, Blaža Tadijanovića), primjeri su stavljeni u kontekst izgradnje hrvatskoga jezikoslovnog nazivlja. Gramatičari su u tvorbi hrvatskoga nazivlja ili doslovno prevodili latinske nazive ili su poštovali tradiciju naziva ako je on već postojao te se sličnost u nazivlju ne objašnjava utjecajem jednoga djela na drugo, nego proširenošću tih naziva u praksi, odnosno uporabnom normom (Raguž 1980-1981: 109, 97). Nove su nazive tvorili i prema već

\footnotetext{
Iste upute sadržava i Šitovićeva gramatika.

Vinjalić uz jezični dio svoje gramatike donosi i dodatak u kojemu su zemljopisno opisane Dalmacija i Bosna i Hercegovina te abecedni indeks s popisom povijesnih ličnosti i događaja povezanih s gore navedenim prostorom, odnosno s današnjom Hrvatskom i Bosnom i Hercegovinom, zapisan samo na talijanskome jeziku. Taj dio također funkcionira kao popis i bogat izvor onomastičke građe pisane trima jezicima s hrvatskim i bosanskim imenima rijeka, jezera, planina, otoka, pa i šire, uz kraća tumačenja na talijanskome jeziku.
} 
postojećim modelima u tvorbi hrvatskoga nazivlja. Cilj je stoga pokazati koliko su se u izgradnji hrvatskih naziva dvojica promatranih gramatičara vodila uporabnom normom i već ovjerenim modelima u tvorbi novih naziva. Također će se analizom pokazati koliko su nova rješenja koja su uveli Relković i Vinjalić utjecala na kasnije gramatičare.

Najstariji izvor hrvatske gramatičke terminologije nalazi se u talijanskoj gramatici pisanoj hrvatskim jezikom Gramatika talijanska ukratko ili kratak nauk za naučiti latinski jezik (1649.) Jakova Mikalje. ${ }^{8}$ Gotovo 65 godina nakon Mikalje, zahvaljujući franjevcima Tomi Babiću i Lovri Šitoviću, ponovno se u gramatikama donose hrvatski nazivi i prijevodi pojedinih gramatičkih pravila.

Toma Babić autor je latinske gramatike za prvu obuku ,iliričkih” početnika Prima grammaticae institutio pro tyronibus Illiricis accomodata (Venecija, 1712., ${ }^{2} 1745$.). Lovro Šitović objavio je latinsku gramatiku za ilirsku mladež Grammatica Latino-Illyrica (Venecija, 1713., ${ }^{21742 .) .}$

Šitovićeva i Babićeva gramatika slijede tradiciju tzv. alvaresovskih slovnica. Na prvi se pogled čini paradoksalno, ali ti udžbenici za učenje latinskoga jezika (Babićev i Šitovićev) pružaju više podataka o izgradnji hrvatskoga književnog jezika nego prvi opis hrvatskoga jezika, Kašićeve Institutiones linguae Illyricae, u kojemu se uporaba hrvatskoga jezika zadržava samo na oprimjerivanju latinskih tumačenja (Perić Gavrančić 2015: 58). Promatrajući nazivlje u tim gramatikama, moguće je uočiti Mikaljin utjecaj ne samo na temelju preuzimanja nekih od njegovih naziva nego i u prihvaćanju Mikaljina modela pri tvorbi pokojih vlastitih naziva (Gabrić-Bagarić i Horvat 2008: 122-123).

Šitovićeva je gramatika opširnija, a bila je i bolje prihvaćena od Babićeve. Prema Ragužu (1980-1981: 101) jezikoslovno je nazivlje u tim dvjema gramatikama gotovo identično. Stoga se za potrebe ovoga rada donose primjeri ponajprije iz Šitovićeve gramatike.

\footnotetext{
O tome i o hrvatskim jezikoslovnim nazivima u Vrančićevu rječniku i u Kašićevim djelima pisanim hrvatskim jezikom u kojima se raspravlja o jezičnim temama više u Gabrić-Bagarić i Horvat 2008:116-117.
} 


\section{Analiza odabranih jezikoslovnih naziva}

Gramatika je prema Šitoviću „zanat upravno besiditi i pisati”9 (Šitović 2001: 1). Pored naziva gramatika, za koji izrijekom kaže da je iz grčkoga jezika, te naziva litteratura, koji navodi kao latinsku inačicu, za hrvatske inačice Šitović tvori nazive, prevedenice slovstvo ili slovinstvo, od kojih je druga, prema dosadašnjim spoznajama, ostala na razini hapaksa. U uvodnome dijelu Vinjalić navodi da je gramatika „zanat za uprav besiditi i pisati” (Vinjalić 1809: 2), što je tumačenje koje se podudara sa Šitovićevim. Da je zapravo riječ o antičkoj definiciji, zaključujemo prema podatku iz Belostenčeva rječnika, koji uz natuknicu gramatika (s. v. grammatica, ae) donosi gotovo istu definiciju s napomenom da je preuzima od Cicerona (tj. navuk dobroga govorenja i pisanja, Cic.). U Relkovića je potvrđen naziv gramatika. I Relković i Vinjalić, dakle, rabe naziv gramatika, što je ustaljena posuđenica iz grčkoga jezika.

Šitović u gramatici uočava četiri dijela: littera, syllaba, dictio i oratio, odnosno slovo, silaba, rečenje, govorenje, što se potvrđuje i u Vinjalića: slovo (littera), sastavak (syllaba), rečenje (dictio) i govorenje (oratio). Vrste riječi Vinjalić naziva dila govorenja, a razlikuje: ime ('imenica'), ${ }^{10}$ zaimenak ('zamjenica'), rič ('glagol'), dionstvo ('particip, pridjev'), pristavak ('prijedlog'), priričak ('prilog'), mejumetak ('usklik') i sastavak ('veznik'), što se u potpunosti podudara sa Šitovićevim nazivljem za vrste riječi. Mikalja je prvi za glagol skovao naziv riječ, što je doslovna prevedenica prema latinskomu višeznačnom verbum ('riječ, 'glagol', 'izraz', 'izričaj') i talijanskomu verbo ('riječ', 'glagol') (Gabrić-Bagarić i Horvat 2008: 121). Prema Ragužu (1980-1981: 112, 115, 117, 118, 120) upravo su u Šitovića prvi put potvrđeni nazivi zaimenak, dionstvo, mejumetak, sastavak,

\footnotetext{
9 U ovome radu navode i ekscerpirane primjere donosimo u transkripciji.

10 U kompleksu riječi s deklinacijom Mikalja rabi sustav u kojem je svojevrstan, uvjetno rečeno temeljni naziv ime, od kojega se dodavanjem atributa izvode dvočlani nazivi za posebna značenja. Značenja (ovdje navedena u zagradama) iščitavaju se iz Mikaljinih definicija i dvojezičnih primjera, prezentiranih hijerarhijski. Opis morfoloških kategorija Mikalja počinje tvrdnjom da postoje 'dvi vrste imena': ime stojeće (imenica) i ime ganutivo (pridjev). Oba su naziva prevedenice dvočlanih termina nomen fixum i nomen mobile starijih latinskih gramatika (Jernej 1981: 151). Naziv ime ganutivo rabi i za glagolski trpni pridjev, što je očigledno iz definicije pasiva: 'R(i)ječ trpljeća slovinski nije drugo nego ova r(i)ječ biti s jednim imenom ganutivim, kako na priliku ja jesam učen, ti jesi učen...' Unutar razmatranja o imenicama tvrdi da u hrvatskom razlikujemo 'tri vrste imena stojećega': ime muško ('imenica m. r.'), ime žensko ('imenica ž. r.'), ime ni muško ni žensko ('imenica sr. r.'), ime nadiveno ('vlastito ime'). [...] Slijedom istoga načela 'zamjenica' je namisnik imena, što je Mikaljin hapaks." (Gabrić-Bagarić i Horvat 2008: 119).
} 
priričak. Nazivima rič, sastavak i priričak ${ }^{11}$ koristi se i Relković, dok za imenicu i pridjev rabi višerječne nazive ime samostavno i ime primitljivo (,Nomen, ime od nazivanja, jest dvostruko, to jest: substantivum i adjectivum, samostavno i primitljivo", 1767: 55), a za prijedlog pridstavak. Posljednja su tri naziva Relkovićeve prvopotvrđenice. Iako preuzima tuđicu participium, donosi i hrvatski naziv: „zato se zove dio uzimajući” (1767: 224), što je njegov hapaks nastao prevođenjem latinskoga naziva. Za usklik rabi naziv medjumetak. Vrste riječi Relković također naziva dio govorenja.

Za samoglasnik i suglasnik Relković preuzima već potvrđene hrvatske višerječne nazive slovo glasovito (dotad potvrđeno npr. u Vrančića, Kašića, Mikalje, Šitovića, Della Belle) i slovo neglasovito (dotad potvrđeno npr. u Kašića, Mikalje, Šitovića, Della Belle, Belostenca).

Šitović za rod rabi naziv pleme. U franjevca Tadijanovića, primjerice, uz pleme potvrđuje se i naziv kolino. ${ }^{12}$ Dok obojica navode muško i žensko pleme, Šitović ima pleme neutro, tj. ni jedno ni drugo, a Tadijanović nijedno pleme ili kolino... ni jedno ni drugo. Relković upotrebljava naziv pokolenje i sukladno tomu za srednji rod tvori naziv neznano pokolenje, što je njegova prvopotvrđenica. Vinjalić ne navodi naziv za srednji rod jer, kako sam piše, talijanski jezik ne raspoznaje srednji rod, pa ga i ne navodi u gramatici.

Relković, kao i njegov suvremenik Tadijanović, ${ }^{13}$ za kategorije broja ima prevedenice prema njemačkomu jeziku: jednostavno ili jednostavni broj (njem. einfach. / einfachen Zahl), većji broj, većjestavno ili većjestavni broj (njem. Vielfach). U Relkovića su također potvrđene i tuđice singulariter i pluraliter, ${ }^{14}$ dok Vinjalić ne tumači kategoriju broja hrvatskim jezikom te stoga ne donosi naziv.

Osim tuđice declinatia za sklonidbu se u Relkovića potvrđuje i hrvatski naziv pregibanje/prigibanje. Međutim, objašnjenje da casus ,[j] [est spadanje jednoga imena na sedam načina" (Relković 1767: 58), implicira i uporabu prevedenice spadanje u značenju 'sklonidba'. Za razliku od Relkovićeve gramatike, u kojoj

\footnotetext{
Priričak je poslije u inačicama potvrđen u Đurkovečkoga (prireček) i Mažuranića (prirječak).

O tome v. Horvat i Ramadanović 2012: 330-331.

Za Tadijanovića v. Horvat i Ramadanović 2012: 282.

14 Mikalja jedninu i množinu naziva jedini broj i broj većine, što su prijevodi naziva iz starih talijanskih gramatika (numero del maggiore, numero del più, numero del meno) (v. Gabrić-Bagarić i Horvat 2008:
} 120). 
spadanje upućuje na sklonidbu, u djelima nekih ranijih (npr. u Belostenca, s. v. casus) i kasnijih jezikoslovaca (npr. u Lanosovića, v. 1776: 9-13) naziv spadanje rabi se u značenju 'padež'. U svojoj šest godina prije objavljenoj gramatici Tadijanović, primjerice, sklonidbu naziva prigibanje i prignutje. ${ }^{15}$ Naziv pregibanje preuzimaju neki kasniji gramatičari i leksikografi (npr. Lanosović, Stulli, Mažuranić, Starčević). ${ }^{16}$

Za padež Relković upotrebljava tuđicu casus. Mikalja, primjerice, rabi naziv $k a s$, a Šitović kaž, što su upravo posuđenice (prilagođenice) prema talijanskomu caso i latinskomu casus, prema čemu Šitović također tvori i hrvatski naziv, kalk padnutje.

U okviru talijanske definicije, u talijanskome metajeziku, odmah nakon navođenja vrsta riječi, Vinjalić donosi hrvatske nazive za padeže: imenujući ('nominativ'), porađujući ('genitiv'), dajući ('dativ'), osvađajući ('akuzativ'), zovući ('vokativ'), odnimajući ('ablativ') te sedmi i osmi padež. ${ }^{17}$ Sedmi padež naziva još i ablativ instrumentala. Možemo zaključiti da su nazivi za padeže gotovo isti kao u Šitovićevoj gramatici, ${ }^{18}$ odnosno da je jedina iznimka naziv za ablativ, koji u Šitovića glasi odnosujući. Taj se naziv potvrđuje samo u Šitovićevoj gramatici (Raguž 1980-1981: 116). Iako Vinjalić u definiciji navodi i oprimjerava sedmi i osmi padež (iđem sa štapom, s' Petrom za sedmi padež i jest pukotina u štapu za osmi padež, Vinjalić 1809: 3), u paradigmama u oba broja donosi sklonidbu odabranih imenica kroz samo šest padeža.

Za razliku od Šitovića i Vinjalića Relković se koristi latinskim nazivima za padeže:

... Što je casus? Was ist der Casus?

Jest spadanje jednoga imena na sedam načina; iste ine biege fall, nachwelcher ein Nenn-Wort auf siebenerley weise gebogen wird.

Koliko u slavonskom jeziku ima casusa i kako se imenuju?

\footnotetext{
15 O tome v. Horvat i Ramadanović 2012: 330.

16 V. Ptičar 1987: 72.

17 Vinjalić spomenute hrvatske nazive padeža donosi u talijanskome metajeziku. Kako se oni ne potvrđuju u hrvatskoj inačici definicije, Vinjalić ne donosi naziv za padež općenito.

18 Šitović razlikuje šest padeža (padnutja) u jednini i množini: imenujući ('nominativ'), porađajući ('genitiv'), dajući ('dativ'), osvađajući ('akuzativ'), zovući ('vokativ') i odnosujući ('ablativ'). V. izdanje 2001: 6-7.
} 
1. Nominativus, imenuje jednoga čovika ili stvar govoreći: ovaj čovik; benennet einen Menschen, oder Sach, sagend: der Mensch.

2. Genitiv[us] priokrene poslidnju silabu nominativi ukazujući čiji: ovoga čovika; mit abänderung der lezten Sylbe Nominativi zeiget wessen: das Menschen.

3. Dativus, koji komugod štogod daje i ukazuje komu: ovomu čoviku; der jemanden etwas gibet, und anzeiget wem: dem Menschen.

4. Accusativus, koji čovika tuži ili osvadja, na priliku: ovoga čovika; der den Menschen verklägt, zum Exempel: den Menschen.

5. Vocativus, koji čovika imenom zove govoreći: o čoviče!; der den Menschen mit Nahmen rufet, als: o Mensch!

6. Ablativus, koji s pridstavkom od koju stvar odnaša: od ovoga čovika; der mit der præposition od von jemend etwas nihmt: von dem Menschen.

7. Sedmi Casus, instrumentalis seu societatis, s pridstavkom $s$ ukazuje društvo: s ovim čovikom; mit der præposition $s$ eine Geselschaft anzeiget: mit dem Menschen. (Relković 1767: 58-59).

Tuđice, odnosno neprilagođene nazive padeža, rabi i Mikalja: nominativo, genitivo, dativo, accusativo, ablativo, vocativo, uz napomenu da se oni, kako sam kaže, ,naški” zovu nominativ, genitiv, dativ, akuzativ, vokativ, ablativ, što bi bile posuđenice (Gabrić-Bagarić i Horvat 2008: 117). ${ }^{19}$

Važno je istaknuti da se u padežnome sustavu Relković razlikuje od svojih prethodnika (Kašića, Mikalje, Šitovića, Babića, Della Belle, Tadijanovića) jer ima

\footnotetext{
19 U nekim su starim hrvatskim gramatikama padeži označeni brojevima, npr. u Voltićevoj (o tome više Horvat i Perić Gavrančić u Voltić 2016: 174). Šime Starčević, primjerice, rabi broj ili sintagme prvo padanje, drugo padanje, treće padanje, četvrto padanje, peto padanje, šesto padanje, pri čemu za padež upotrebljava naziv padanje (v. pretisak Starčević 2002: 26). Antun Mažuranić donosi hrvatske nazive padeža i posuđenice (1. imeniteljni ili nominativ, 2. roditeljni ili genitiv, 3. dateljni ili dativ, 4. tužiteljni ili accusativ, 5. zvateljni ili vocativ, 6. městni ili local, 7. orudni ili instrumental, v. pretisak Mažuranić 2008: 55), ali se u sklonidbenim paradigmama služi samo brojevima padeža (pretisak Mažuranić 2008: 56-58, 62), dok u objašnjenjima katkad rabi naziv („Roditeljni višebroja načinja-se [...]”, v. Mažuranić 2008: 60), a katkad sintagmu s brojem (npr. „U petom padežu jednobroja pred e pretvara-se c i k [...]”, v. Mažuranić 2008: 58). Hrvatski su nazivi potvrđeni i u gramatici kajkavskoga književnog jezika Josipa Đurkovečkog (v. Lewis, Štebih i Vajs 2006: 189).
} 
sedam padeža u jednini i množini. Nije uočio lokativ, šesti mu je padež ablativ, a sedmi instrumental. ${ }^{20}$

U Relkovićevoj je gramatici poglavlje o glagolima jedno od najvećih te je i nazivlje za glagolska vremena vrlo razgranato. Relković razlikuje vrime sadašnje (tempus praesens), prošasto (praeteritum) i došasto (futurum), a ,[o]d ovih nika su simplicia, a nika composita, to jest samostavna i sastavljena" (Relković 1767: 127), što upućuje na to da je uočio jednostavne i složene glagolske oblike. Nazivi vrijeme sadašnje i vrijeme prošasto Mikaljine su prvopotvrđenice (od kojih se druga odnosi na 'perfekt/aorist'). Međutim, dok Mikalja u svojoj gramatici za futur donosi opisni naziv vrijeme koje ima doći, franjevački gramatičar Toma Babić prvi je upotrijebio višerječni naziv došasto vrime, ${ }^{21}$ što se poslije potvrđuje u Šitovića, Relkovića, Lanosovića, Vinjalića. Stoga je moguće pretpostaviti da je naziv došasto vrime Babić tvorio po uzoru na Mikaljine dvorječne tvorenice sa sastvanicom vrijeme $e^{22}$, a naziv su preuzeli kasniji gramatičari.

Relkovićeve su prvopotvrđenice npr. nazivi vrime polak prošasto ('imperfekt') i cilo prošasto ('pluskvamperfekt'), dok su na razini hapaksa ostali njegovi nazivi vrime prošasto samostavno ('aorist', prema lat. perfectum simplex) i vrime prošasto sastavljeno ('perfekt', prema lat. perfectum compositum). Za pluskvamperfekt potvrđen je i naziv vrime prošasto svršeno. Prema Pranjkoviću upravo je poglavlje o glagolima jedno od najkompliciranijih i najspornijih jer je, među ostalim, ,za gotovo sve njemačke konjunktive Relković nastojao pronaći slavonske adekvate”, a „očit je i utjecaj latinskih gramatika (uglavnom preko starije hrvatske gramatičke tradicije)" (Pranjković 1985: 107).

Od naziva za glagolski način Vinjalić navodi samo naziv za indikativ kao prijevod latinskoga višerječnog naziva indicativi modi tempus praesens: ukazujućega načina vrime sadanje. Potom redom donosi nazive za glagolska vremena u definiciji koja slijedi iza latinske i talijanske definicije: prošasto nesvršeno (praete-

\footnotetext{
20 Prvi je paradigmu od sedam padeža u jednini i množini u suvremenom smislu uveo Ignjat Alojzije Brlić u svojoj gramatici Grammatik der illyrischen Sprache (1833.), s tim što je lokativ sedmi, a instrumental šesti padež.

$21 \quad$ Za naziv došasto vrime usp. Ptičar 1987: 68.

22 Usp. npr. Mikaljine nazive vrijeme sadašnje i vrijeme prošasto.
} 
ritum imperfectum), prošasto svršeno (praeteritum perfect), veće nego svršeno (praeteritum plusquamperfect) i došasto (futurum) (Vinjalić 1809: 58). ${ }^{23}$

U dosta složenim i razgranatim paradigmama za glagolska vremena i načine, kojima je Vinjalić želio pokazati da se hrvatskim jezikom mogu izraziti talijanski konjunktivi (Vinjalić 1809: 42), rijetko se kad mogu uočiti pravilnosti pa, primjerice, vrijeme prošasto svršeno ne podrazumijeva uvijek samo aorist i perfekt, kako je to navedeno u primjeru konjugacije glagola biti. Za razliku od Vinjalića, koji ostale glagolske načine navodi samo na latinskome jeziku, Relković donosi i hrvatske nazive, npr. kazujući način (indicativus modus), nesvršeni način (infinitivus modus), ukazujući način (indicativus modus), zapovidajući način (imperativus modus), želeći $i$ vežući način (optativus \& conjunctivus modus). ${ }^{24}$ Naziv kazujući način bio bi Relkovićev hapaks, a vežući način njegova prvopotvrđenica. Naziv ukazujući način Babićeva je prvopotvrđenica, dok je Šitović tvorac naziva nesvršeni način, zapovidajući način i željeći način. ${ }^{25}$ Mikalja je, primjerice, načine imenovao opisno: način koji kaže ('indikativ'), način koji zapovijeda/zapovida ('imperativ'), način koji sastavlja ('konjunktiv'), način koji žudi ('optativ'), način koji ne svršuje ('infinitiv'). Sam naziv način potječe upravo od Mikalje, koji ga kao izravan prijevod latinskoga modus uvodi u hrvatsko gramatičko nazivlje.

Iako u svojoj gramatici Vinjalić ne navodi detaljnije nazive za imenske riječi ili glagole, osim naziva za glagolska vremena, zamjetno je da dosta detaljno opisuje veznike. Tako navodi nazive za vrste veznika: sastavljajući ili vezajući (,i, a, još”, Vinjalić 1809: 183), rastavljajući (,ili, iliti, ali, li”, Vinjalić 1809: 183), protiveći (,ni, niti, ne; premda, dobro da, sa svim tizim, zasveda, makar; ništanemanje”, Vinjalić 1809: 184), skupljajući ili iznoseći ili razložiti (,dakle, tot dakle, za radi šta, šta radi, za radi šta, česa radi, rad toga, kros to, radi šta, radi česa, zato, cijeća toga, zato”, Vinjalić 1809: 184), uzrokljivi (,,bo, jerbo, jer, jer jer, pokle kada, zašto bo, jere, zato, cića, radi toga, jer, cića toga, zato, jer", Vinjalić 1809: 184), ugovorljivi ili akovljivi (,ako da, ako ne, nego da, veće ako,

\footnotetext{
${ }_{23}$ Za usporedbu ističemo kako Šitović navodi isto nazivlje za glagolska vremena: prošasto nesvršeno za imperfekt, prošasto svršeno za aorist i perfekt, prošasto veće nego svršeno za pluskvamperfekt, došasto za futur.

24 Relković nazive donosi na latinskome, hrvatskome i njemačkome jeziku.

25 Usp. Ptičar 1987: 70-71, 75-76.
} 
istom, istom da, samo da", Vinjalić 1809: 184), izpuneći (,doisto, zaisto, istinito", Vinjalić 1809: 184).

Očito je Vinjalićevo ugledanje na Šitovića, u kojega se potvrđuju ovi nazivi: vezajući ili sastavljajući, rastavljajući, protiveći, skupljajući ili iznoseći ili razložiti, uzrokljivi, akovljivi, izpuneći. I Vinjalić i Šitović veznike dijele prema položaju u rečenici, odnosno prema tomu jesu li veznici anteponirani ili postponirani, što je također utjecaj latinske gramatike: „Sastavci dio jesu pristavljajući, dio podlagajući, a dio sridnji” (Šitović 2001: 120, Vinjalić 1809: 185).

Relković veznike (tj. sastavke) dijeli na: vežuće, rastavljajuće, protiveće, uzrokujuće, zatvarajuće, izvadijuće, nakanljive. ${ }^{26}$ Vidimo da, u odnosu na Šitovića i Vinjalića kod kojih se potvrđuje naziv vezajući, Relković ima naziv vežući, koji će poslije preuzeti Lanosović. Relković također tvori tri nova naziva: zatvarajući (prema lat. conjuctiones conclusive), ${ }^{27}$ izvadijući (prema lat. conjuctiones exceptivae), ${ }^{28}$ nakanljivi (prema lat. conjuctiones conditionales), ${ }^{29}$ od kojih se prvi (zatvarajući) poslije potvrđuje u Lanosovića.

Pored posuđenice ortografija u Relkovića su potvrđeni i hrvatski nazivi pravopisanje i slovosložnost. Oba su naziva njegove prvopotvrđenice jer, primjerice, Mikalja uz ortografiju navodi opisni naziv način od pisanja. Naziv zlamenje za pravopisni znak potvrđuje se, primjerice, u Tadijanovića, Relkovića, poslije u Starčevića, dok se Šitoviću naziv zlamenje odnosi na 'značenje'. Budući da Relković dosta iscrpno obrađuje pravopis, proširuje i nazivlje o pravopisnim znakovima: zlamenje ('pravopisni znak'): zlamenje ostavljenja (apostrophus), zlamenje pitanja (signum interogationis), zlamenje podvikanja ili začuđenja (s. exclamationis ili admirationis), zlamenje razdilenja (točka, zarez, točka i zarez, dvotočka i crta; punctuation), zlamenje svezanja ('crta'), zlamenje umišanja ('zagrada'). Tadijanović, primjerice, ne imenuje svaki pravopisni znak zasebno, nego ih naziva prvo, drugo, treće, četvrto, peto i šesto zlamenje.

\footnotetext{
26 O podjeli veznika u skupine v. Relković 1767: 243-245.

27 U tu skupinu ubraja: tako, najposli, dakle, zaradi toga, slidećim načinom, cića toga, na taj način, od ostaloga, jednom ričju, indi.

28 U tu skupinu ubraja: izvan, ako ne, osim, već ako.

29 U tu skupinu ubraja: ako, akoli, ako ne, s ovim načinom, ako bi možebit, ako Bog da, ako bude Božja volja, da samo, postavimo, ako bi kojom talijom.
} 


\section{Zaključak}

Ovim radom nastojalo se pridonijeti istraživanju bogatoga hrvatskog jezikoslovnog nazivlja dopreporodnoga razdoblja. Iako je Mikaljina slovnica najstariji izvor hrvatskoga gramatičkog nazivlja, Babićeva te posebice Šitovićeva, kao prve gramatike s hrvatskim nazivljem nakon Mikaljine, također su u mnogočemu bile prethodnice u tvorbi hrvatskoga jezikoslovnog nazivlja.

Relković i Vinjalić u svojim su gramatikama prihvaćali one nazive koji su bili ovjereni uporabom, odnosno koji su bili potvrđeni u dotadašnjim djelima, prije svega u postojećim rječnicima i gramatikama, ali su tražili i vlastita rješenja, preuzimajući tuđice, kreirajući posuđenice ili stvarajući nove nazive prevođenjem stranih, većinom latinskih te talijanskih i njemačkih naziva. Time su slijedili dotadašnju praksu stvaranja hrvatskoga nazivlja.

Zamjetno je da se Vinjalićevo nazivlje u mnogočemu podudara sa Šitovićevim (posebice nazivi za vrste riječi, padeže i veznike), što je moguće protumačiti uporabom toga nazivlja na franjevačkim kolegijima za koji su te dvije gramatike i bile pisane. Te se gramatike oslanjaju na tradiciju latinskih gramatika, pa je i promatrano nazivlje skovano prema latinskomu, bez obzira na to je li riječ o posuđenicama (prilagođenicama) ili o prevedenicama. Relković je, s druge strane, uz očit utjecaj latinskoga jezika, bio i pod utjecajem njemačkih gramatika. Kao i njegovi prethodnici, Relković se istaknuo i kao tvorac novih naziva, primjerice ime samostavno, ime primitljivo, pridstavak, neznano pokoljenje, vrime polak prošasto, cilo prošasto, vrime prošasto samostavno i vrime prošasto sastavljeno, kazujući način, vežući način, pravopisanje, slovosložnost. Kako su neki primijećeni i u kasnijih gramatičara, utjecali su na razvoj hrvatskoga dopreporodnog jezikoslovnog nazivlja. Vinjalićeva gramatika, s puno manje potvrđenih hrvatskih naziva od Relkovićeve, očekivano nije mogla utjecati na kasnije gramatičare jer nije bila objavljena tiskom. Uostalom, kao gramatika koja se u velikoj mjeri oslanja na gramatike franjevačke tradicije, prije svega na Šitovićevu gramatiku, ne donosi neke novine u nazivlju, ali potvrđuje postojanje stabilne uporabne norme na franjevačkim kolegijima. 


\section{Izvori:}

Relković, Matija Antun. ${ }^{1} 1767$. Nova slavonska, i nimačka gramatika / Neue Slavonische und Deutsche Grammatik. Zagreb.

VInJALIĆ, GAŠPAR. 1809. Principi della grammatica ad uso de Slavi che desiderano esser Religiosi com quali apprenderano nell'istesso tempo la Lingua Latina ed Italiana, servirà anco agli Italiani per apprender la Lingua Slava. Opera di Fra Gasparo Vignalich ex Diffinitor dell'Osservante Provinzia dell Santissimo Redentor in Dalmazia. Grammatica prima in lingua slava, italiana et latina (rukopis). Franjevački samostan u Sinju. Sign. I./2.

\section{Literatura:}

Belostenec, Ivan. 1740. Gazophylacium, seu Latino-Illyricorum onomatum aerarium. Gazophylacium Illyrico-Latinum. Zagreb.

Bratulić, Josip. 2013. Slavonske književnopovijesne teme. Privlačica. Zagreb.

Brlobaš, ŽElJKA; HoRvat, MariJAnA. 2006. Fonološko nazivlje u hrvatskim gramatikama 19. stoljeća. Filologija 46-47. 49-66.

Demo, Šme. 2007. Od Latinske slovnice do Latinske gramatike. Filologija 49. 37-49.

Gabrić-Bagarić, DariJa. 1997. Lingvističko nazivlje u djelima starih jezikoslovaca i prevoditelja. Prvi slavistički kongres: Zbornik radova I. Gl. ur. Damjanović, Stjepan. Hrvatsko filološko društvo. Zagreb. 55-63.

Gabrić-Bagarić, Darija; Horvat, MariJana. 2008. Gramatika talijanska ukratko (1649.) Jakova Mikalje. U: Mikalja, Jakov. Gramatika talijanska ukratko ili kratak nauk za naučiti latinski jezik (pretisak). Ur. Znika, Marija. Institut za hrvatski jezik i jezikoslovlje. Zagreb. 105-185.

Horvat, Marijana; Ramadanović, Ermina. 2012. Jezikoslovni priručnik Blaža Tadijanovića Svašta po malo iliti kratko složenje imena i riči u ilirski i njemački jezik (1761.). Institut za hrvatski jezik i jezikoslovlje. Zagreb.

Horvat, Marijana; Perić Gavrančić, Sanja. 2016. Život i djelo Josipa Voltića. U: Voltić, Josip. Grammatica Illirica / Ilirska gramatika (1803.). Institut za hrvatski jezik i jezikoslovlje. Zagreb. 137-185.

Kolenić, Luiljana. 2006. Pogled u tvorbu staroga hrvatskoga gramatičkog nazivlja. Filologija 46-47. 151-164.

Kramarić, Martina. 2020. Prilog istraživanju hrvatske sastavnice rukopisne gramatike Principi della grammatica [...] Grammatica prima in lingua slava, italiana et latina Gašpara Vinjalića. Filologija 74. 17-48. doi.org/https://dx.doi.org/10.21857/yq32oh2ew9. 
LANOSOVIĆ, MARIJAN. 1776. Uvod u latinsko riči slaganje s nikima nimačkog jezika biližkama za korist slovinskih mladića složen. Osijek.

Lewis, Kristian; Štebih, Barbara; Vajs, Nada. 2006. Gramatičko nazivlje u hrvatskome kajkavskome književnom jeziku. Filologija 46-47. 183-201.

Maretić, Tomo. 1932. Pregled srpskohrvatske gramatičke terminologije XVII, XVIII i XIX vijeka. Rad JAZU 243. 13-90.

Matija Antun Relković i Slavonija 18. stoljeća: radovi sa znanstvenoga skupa (u povodu 200. godišnjice smrti), Zagreb - Vinkovci - Davor, 24. - 25. travnja 1998. 2000. Ur. Bogdan, Tomislav. Općinsko poglavarstvo. Davor - Zagreb.

Mažuranić, Antun. 2008. Slovnica Hèrvatska. Pretisak izdanja iz 1859. Institut za hrvatski jezik i jezikoslovlje. Zagreb.

Perić GaVRančić, SANJa. 2015. Lanosovićev prinos izgradnji hrvatskoga jezikoslovnoga nazivlja. Hrvatski jezik i pisana riječ XVII. i XVIII. stoljeća: zbornik radova. Ur. Samardžija, Marko. Privlačica. Vinkovci. 56-60.

PranjKović, Ivo. 1985. Gramatika Matije Antuna Relkovića. Croatica: Prinosi proučavanju hrvatske književnosti XVI (22/23). 97-119.

PTIČAR, Adela. 1987. Gramatička terminologija u gramatici M. A. Relkovića. Rasprave Zavoda za jezik 13. 65-78.

PtiČAr, Adela. 1992. Prinos proučavanju jezikoslovnoga nazivlja 18. stoljeća. Rasprave Zavoda za jezik 18. 151-156.

RAGUŽ, Dragutin. 1980-1981. Hrvatska gramatička terminologija u dvjema preradbama Alvaresove latinske gramatike. Filologija 10. 97-125.

StarČević, Šime. 2002. Nova ričoslovica ilirička. Pretisak izdanja iz 1812. Institut za hrvatski jezik i jezikoslovlje. Zagreb.

Šitović, Lovro. 2001. Grammatica Latino-Illyrica. Pretisak gramatike iz 1713. Predgovor i pogovor: fra Andrija Nikić. Franjevačka knjižnica i arhiv. Mostar - Klobuk.

Vrijeme i djelo Matije Antuna Reljkovića. 1991. Ur. Čalić, Dušan. Jugoslavenska akademija znanosti i umjetnosti. Zavod za znanstveni rad Osijek. Osijek. 


\section{Grammatical Terminology in the Grammars of M. A. Relković and G. Vinjalić}

\section{Abstract}

The subject of this article is Croatian linguistic terminology in two Croatian grammars of the $18^{\text {th }}$ century.

M. A. Relković is the author of an extremely extensive grammar entitled Nova slavonska, i nimačka gramatika ('1767). Relković's handbook is a German-Croatian contrastive grammar; paradigms and grammatical rules are given in Croatian and in German. The base of his grammar is the Stokavian Ikavian dialect. Relković wrote his handbook under the influence of Enlightenment ideas, his intention was not only to cultivate his mother tongue but also to encourage young Croats to learn German and vice versa. Relković's grammar is a general language manual, for which the models existed in Croatian and European language manuals. It is also an extensive source of linguistic terminology (Croatian, Latin, and German).

G. Vinjalić wrote a trilingual grammar Principi della grammatica [...] Grammatica prima in lingua slava, italiana et latina in the middle of the $18^{\text {th }}$ century but it is preserved in the manuscript from 1809. Since the grammar is still unpublished and there are not many well-known data about it, it has not been in the focus of scholarly interest so far. As the author himself explains, the grammar was written for Franciscan schools and their students who were to become priests and who wanted to learn Croatian, as well as Italian and Latin. Therefore, the grammar is compiled as a trilingual grammar: the grammatical rules are mainly written in Latin and Italian, but the examples are written in all three languages.

As the above-mentioned authors used similar terminology as their predecessors, attested examples were placed in the context of the creation of Croatian linguistic terminology in general. Linguistic terminology in both grammars is in accordance with the contemporary usage norm in vocabularies, grammars, and other literary texts of the time. This paper also shows to what extent the analysed linguistic terminology influenced future grammar. The authors conclude that Relkovic with his grammar and neologisms has made a stronger impact on future grammar books than Vinjalić's manuscript grammar.

Ključne riječi: dopreporodne gramatike, jezikoslovno nazivlje, Relković Nova slavonska, i nimačka gramatika, Vinjalić Principi della grammatica [...] Grammatica prima in lingua Slava, Italiana et Latina

Keywords: pre-standard Croatian grammars, linguistic terminology, Relković Nova slavonska, i nimačka gramatika, Vinjalić Principi della grammatica [...] Grammatica prima in lingua slava, italiana et latina 
Rasprave 46/1 (2020.) str. 93-109 